\title{
Virtual learning object in hematopoietic stem cell transplantation for autoimmune diseases
}

\author{
Objeto virtual de aprendizagem no transplante de células-tronco hematopoéticas para doenças autoimunes
}

Objeto virtual de aprendizaje en el trasplante de células madre hematopoyéticas para enfermedades autoinmunes

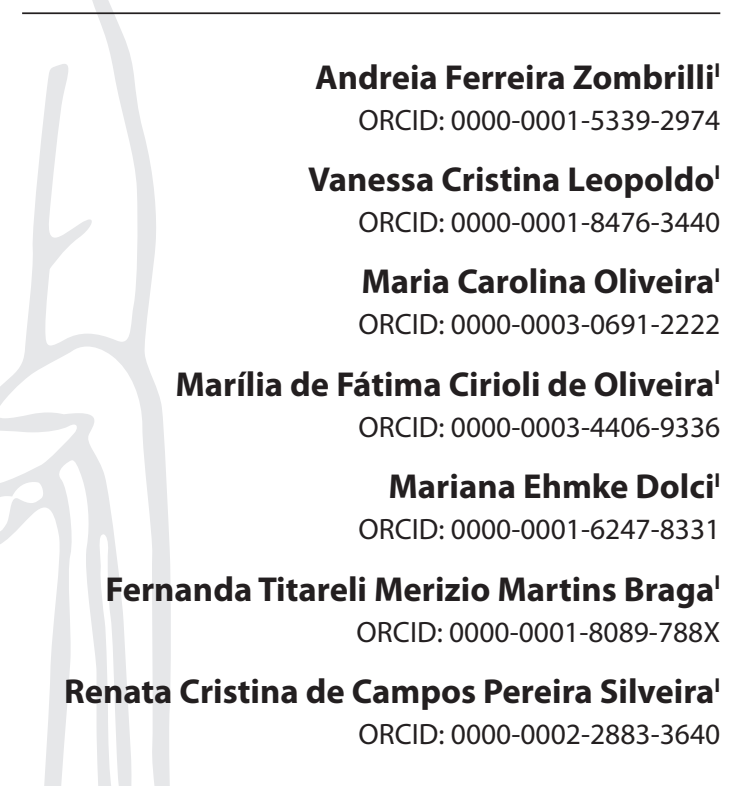

'Universidade de São Paulo. Ribeirão Preto, São Paulo, Brazil.

How to cite this article: Zombrilli AF, Leopoldo VC, Oliveira MC, Oliveira MFC, Dolci ME, Braga FTMM, Silveira RCCP. Virtual learning object in hematopoietic stem cell transplantation for autoimmune diseases. Rev Bras Enferm. 2019;72(4):994-1000. doi: http://dx.doi.org/10.1590/0034-7167-2018-0669

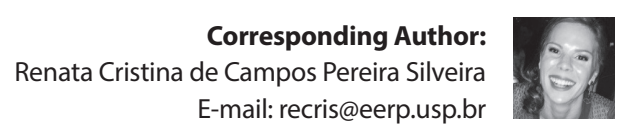

Submission: 04-22-2019

Approval: 11-04-2018

\begin{abstract}
Objective: describe the development of a virtual learning object to provide information about autologous transplantation of hematopoietic stem cells to autoimmune diseases. Methods: methodological study of a website development, using the instructional design model that includes Analysis, Design, Development and Implementation. Results: the virtual object, available at http://www.transplantardai.com.br, was developed in a web platform, in the Hypertext Markup Language, using the software WebAcappella Responsive Website Creator (Intuisphere, France 2016). The content was structured in the modules: History, Transplant, Autoimmune Diseases, Links, Guidelines, Speech Team and Doubts. The icons and menus were created in order to attract the user, facilitating the search for information and allowing maximum use of the resources available on the website. Conclusion: the methodology used allowed the development of the virtual learning object, which can be used as a tool to guide and disseminate knowledge about this treatment.

Descriptors: Hematopoietic Stem Cell Transplantation; Autoimmune Diseases; Teaching Materials; Education, Distance; Internet.
\end{abstract}

\section{RESUMO}

Objetivo: descrever o desenvolvimento de um objeto virtual de aprendizagem para disponibilização de informações sobre transplante autólogo de células-tronco hematopoéticas para doenças autoimunes. Métodos: estudo metodológico de desenvolvimento de um website, empregando o modelo de design instrucional que envolve Análise, Design, Desenvolvimento e Implementação. Resultados: o objeto virtual, disponível no endereço eletrônico http://www.transplantardai.com.br, foi desenvolvido em plataforma web, na linguagem de marcação Hypertext Markup Language, utilizando-se o software WebAcappella - Responsive Website Creator (Intuisphere, França 2016). O conteúdo foi estruturado nos seguintes módulos: História, Transplante, Doenças Autoimunes, Links, Orientações, Fala Equipe e Dúvidas. Os ícones e menus foram criados de modo a atrair o usuário, facilitando a busca de informações e permitindo máximo uso dos recursos disponíveis no website. Conclusão: a metodologia empregada permitiu o desenvolvimento do objeto virtual de aprendizagem, que poderá ser utilizado como ferramenta para orientar e disseminar o conhecimento sobre esse tratamento.

Descritores: Transplante de Células-Tronco Hematopoéticas; Doenças Autoimunes; Materiais de Ensino; Educação a Distância; Internet.

\section{RESUMEN}

Objetivo: describir el desarrollo de un objeto de aprendizaje virtual para proporcionar información sobre el trasplante autólogo de células madre hematopoyéticas en las enfermedades autoinmunes. Métodos: estudio metodológico del desarrollo del sitio web, utilizando el modelo de diseño instruccional (Análisis, Diseño, Desarrollo e Implementación). Resultados: el objeto virtual, disponible en http://www.transplantardai.com.br, fue desarrollado en una plataforma web, en el lenguaje de marcación Hypertext Markup Language, utilizando el software WebAcappella - Responsive Website Creator (Intuisphere, Francia 2016). El contenido se estructuró en los módulos: Historia, Trasplante, Enfermedades Autoinmunes, Links, Guías, Habla Equipo y Dudas. Los iconos y menús fueron creados para atraer al usuario, facilitando la búsqueda de información y permitiendo el máximo aprovechamiento de los recursos disponibles en el sitio web. Conclusión: la metodología utilizada permitió el desarrollo del objeto de aprendizaje virtual, que puede ser utilizado como una herramienta para guiar y difundir el conocimiento sobre este tratamiento. Descriptores: Trasplante de Células Madre Hematopoyéticas; Enfermedades Autoinmunes; Materiales de Enseñanza; Educación a Distancia; Internet. 


\section{INTRODUCTION}

Autologous hematopoietic stem cell transplantation (AHSCT) has been indicated for the treatment of patients with autoimmune diseases, often associated with high morbidity and mortality rates and affecting the quality of life ${ }^{(1)}$. Hundreds of patients with autoimmune diseases have already been transplanted in many centers around the world, most of them evaluated by phase I/ Il studies, with positive results ${ }^{(1-4)}$. More recently, randomized phase III studies showed superiority of AHSCT when compared to conventional treatment ${ }^{(1,3,5)}$. The procedure is very invasive, expensive, and associated with several side effects, as well as potential complications and physical and psychological stress factors experienced by patients and their families ${ }^{(2)}$.

In autologous transplantation, the hematopoietic stem cells are removed from the patient. The procedure is divided into three phases: pre-AHSCT evaluation, mobilization of hematopoietic stem cells and conditioning for transplantation. In the pre-transplantation phase, medical and multiprofessional evaluations determine whether a patient fulfills indication criteria ${ }^{(6)}$. In the mobilization phase, the patient receives drug stimulus to increase the number of hematopoietic stem cells within the bone marrow and then circulate in the peripheral blood, from where they are collected by apheresis and stored at low temperatures. In the next phase, from conditioning to transplantation, the patient receives high doses of chemotherapy and immunotherapy followed by infusion of stem cells. In the approximate period of 10 days, the marrow returns to produce blood cells and the patient is able to receive hospital discharge.

The immediate outpatient monitoring post-AHSCT lasts about 60 days, in this period the patient stays in the city of the transplant center. After that, if the patient shows the adequate clinical conditions, is allowed to return to the home city, with regular outpatient check-ups for up to five years.

During the transplantation period, the patient must acquire new knowledge and skills, adapt to the conditions imposed by the therapy, gather the necessary resources and engage in the recovery process, which, together, are characterized as self-care actions $^{(7)}$. The nursing team participates actively and intensively in the transplantation, accompanying the patient during all stages of the procedure, assisting him in his needs, disabilities, limitations and difficulties. However, the patient and his companion act as active elements of the process and not only as spectators of the actions of health professionals ${ }^{(8-9)}$. In this context, it is essential that the patient understands and participates in each stage of the transplantation in order to improve the effectiveness and safety of the procedure ${ }^{(8,10-11)}$.

Teaching strategies should be adapted to the individual learning needs of each patient. Adopt a learning theory and applying it in the context of a transplant can generate scientific knowledge and allow it to be transferred to the clinical practice, contributing to the success of the transplant. Informatics can facilitate learning, as it allows to present the same content from different media and angles. Movements, scenarios, sounds, colors allow the integration of the rational with the affective, the deductive with the inductive, the space with the time, the concrete with the abstract ${ }^{(12)}$.
In 1963, Ausubel described a pedagogical theory proposing the valorization of the subject's previous knowledge and the search for knowledge ${ }^{(13)}$. From this perspective, learning depends on the individual's desire to learn. A meaningful learning occurs when new knowledge begins to mean something to the learner and the learner is able to explain it in his own words and solve new problems. For learning success, three conditions are necessary: the material must be constructed in a structured and logical way, potentially significant; the learner must have cognitive capacity to understand and relate the acquired content; the learner must be motivated to integrate the new knowledge $\mathrm{e}^{(12,14)}$. Additionally, according to Moreira, Caballero and Rodriguez ${ }^{(12)}$, it is conditional that the material used may be logical and not arbitrary, with adequate and relevant cognitive structure ${ }^{(12)}$.

The learner should have in his cognitive structure anchor ideas with which the material is related. The learning becomes meaningful when it attributes meanings to the knowledge received, relating to previous knowledge. The cognitive structure of the human being is organized in a hierarchical manner, and the acquisition of knowledge is easier if it occurs according to a progressive differentiation ${ }^{(12,14)}$. In addition, the content should highlight relevant differences and similarities, relate concepts and propositions, and harmonize actual or apparent inconsistencies.

Thus, the development of the virtual object that provides information about the hematopoietic stem cell transplantation for autoimmune diseases aims that patients and caregivers develop new meanings, contributing to their learning and to promoting the solution of problems. It is notorious the expansion of the use of the Internet, as well as its relative democratization as a resource that facilitates communication in many social contexts. Additionally, in order for a effective distance education, the use of Virtual Learning Objects is necessary ${ }^{(15-17)}$. Thus, due to the scarcity of information and specialized guidance in all phases of AHSCT, we detected the need to develop a virtual learning object (VLO) as a tool for knowledge acquisition, in a simple and fast way.

\section{OBJECTIVE}

Describe the development of a VLO that provides information about autologous hematopoietic stem cell transplantation for autoimmune diseases.

\section{METHODS}

\section{Ethical aspects}

Since this is a study to develop a pedagogical resource, without direct contact with patients and/or data derived from them, the approval by the Research Ethics Committee was not necessary.

\section{Study design}

This is a methodological study ${ }^{(17)}$ for the construction of a website type VLO, with the aim of providing patients and caregivers with information about AHSCT for autoimmune diseases with fast and reliable access to educational materials. The STROBE instrument was used to guide the design of this study. 


\section{Study protocol}

The VLO was built according to the instructional design model ADDIE $^{(18)}$ (Analysis, Design, Development, Implementation and Evaluation). In the analysis phase, we evaluated the context identifying the learning needs, characterizing the target audience, lifting the restrictions (technical limitations), and defining the content.

As this is a recent therapeutic modality, consistently reported in the literature for no more than two decades, the narrative review of the literature was exhaustive $\mathrm{e}^{(1-6,19-30)}$, exploring all possible sources of information about the subject. We emphasize that the scientific production of the research group about nursing care subsidized the construction of the available information ${ }^{(31-32)}$. In addition, we used informative manuals with the unit's routine, institutional research protocols and national publications of recommendations developed in partnership with the Brazilian Society of Bone Marrow Transplantation ${ }^{(33)}$. We provided information about autoimmune diseases and educational materials about the treatment in the website link containing interviews recorded by professionals. The manuals and protocols were available for this study by the coordinator of the unity. Images and videos were extracted from the personal files of the researchers and also from Internet ${ }^{\circ}$ sites, using free permission, and all of them were referenced. When necessary, we applied image and voice authorization terms.

In phase 2, Design, we used all the information from the analysis stage to define the objectives and procedures that would be adopted to achieve them. For this purpose, we mapped and sequenced the contents, defined the strategies and selected the media. The material was organized in a clear and comprehensive manner, with simplified language. The images and multimedia elements were subtitled and we used short paragraphs and sentences.

In the next stage, Development, we prepared materials and instructional products. We divided the content into modules, and these, into topics. A professional in Information Technology (IT) created a prototype of the VLO homepage and, thus, the researcher established the color standards, font format and size, and the background color. Next, the IT professional made the conversion of all proposed theoretical material to the VLO, under the supervision of the researcher. VLO was developed in a web platform, in HTML markup language. This language was chosen because it is multiplatform and can be accessed by many equipment (computers, tablets, mobile phones) using the software WebAcappella - Responsive Website Creator (Intuisphere - France, 2016) ${ }^{(34)}$. It is a free software, with good resources for development of websites with responsive technology, making it more flexible and adaptable to the media. Navigation structure, hypertext construction, maintenance and graphical assembly of the theoretical content were under the responsibility of the IT professional.

The Implementation phase consisted of making VLO available on the web for free access of users, starting in January, 2018. The VLO was also presented to all members of the interdisciplinary team of the Immunological Therapy Unit by the main researcher.

Finally, the Evaluation phase consists in monitoring, review and maintenance of the proposed system. It will be done according to the number of accesses to the site, feedback from patients under treatment in the unit and the validation of appearance and content that will be done in the future by professionals in the area, patients and caregivers.

\section{RESULTS}

The VLO containing information about AHSCT for autoimmune diseases was developed according to the steps of the instructional design model described and is available at the public domain electronic address <http://www.transplantardai.com.br $>$, registered at the Registro BR and hosted on the online server of the IT professional who helped to develop the site.

The thematic axis of VLO was based on essential information to elucidate patients living with autoimmune diseases, potential candidates for AHSCT, as well as to inform their families or caregivers about this therapy.

The modules are divided into seven topics: History, reporting a brief trajectory of AHSCT in Brazil. Transplantation, explaining the procedure, exposing its phases and side effects. Autoimmune Diseases, to share information about the main autoimmune diseases treated with AHSCT (systemic sclerosis, multiple sclerosis, systemic lupus erythematosus and type 1 diabetes mellitus). Guidelines, exposing specific care for the phases of hospitalization and hospital discharge. Interesting Links, allowing quick access to content for reading and other materials about the theme, such as educational videos and interviews of specialists. Speech Team, containing guidance of professionals who work in the Immunological Therapy Unit, separated according to the specialties of the multidisciplinary team: Medicine, Physiotherapy and Psychology. Finally, Frequently Asked Questions, answering the main questions exposed by patients in clinical practice.

When entering the address, the user will see the home page of the website entitled "Transplantar" (transplant) (Figure 1). We chose this title because it is simple and objective, in accordance with the proposal of the website to inform, in a clear and objective way, patients and relatives.

Also on this home page, the user will have access to a welcome text and guidelines about content, purpose, contact and authorship of the VLO. The taskbar is located at the top of the screen, in a horizontal direction, presenting the navigation modules divided by topics: History, Transplant, Autoimmune diseases, Links, Guidelines (Figure 2), Speech team (Figure 3) and Doubts (Figure 4).

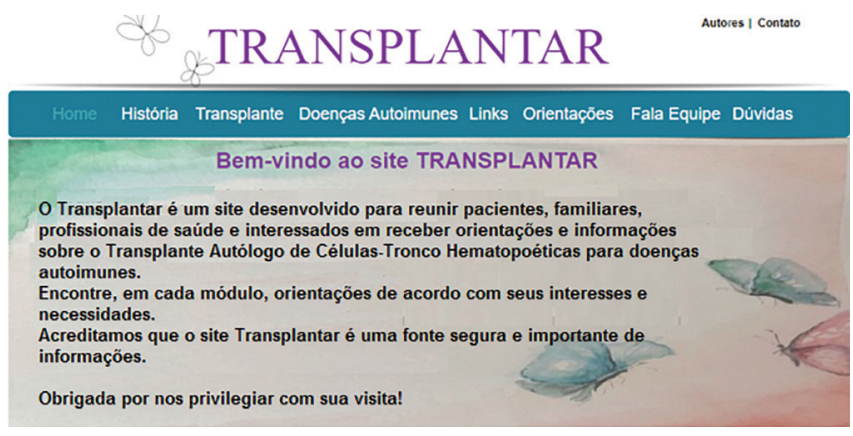

Source: $h$ ttp://www.transplantardai.com.br/

Figure 1 - Presentation of the initial screen of the Virtual Learning Object website Transplantar, Ribeirão Preto, São Paulo, Brazil, 2017 


\section{TRANSPLANTAR}

Autores I Contato

Home Historia Transplante Doenças Autoimunes Links

Orientações

Como o transplante de medula óssea é um procedimento bastante complexo e de alto risco

os pacientes precisam seguir rotinas e cuidados especificos em todas as fases do

tratamento. Confira as orientações para as fases de internação e alta hospitalar:

$$
\text { INTERNAÇÃO }
$$

\section{ALTA}

Source: $h$ ttp://www.transplantardai.com.br/

Figure 2 - Presentation of the screen Guidelines of the Virtual Learning Object website Transplantar, Ribeirão Preto, São Paulo, Brazil, 2017

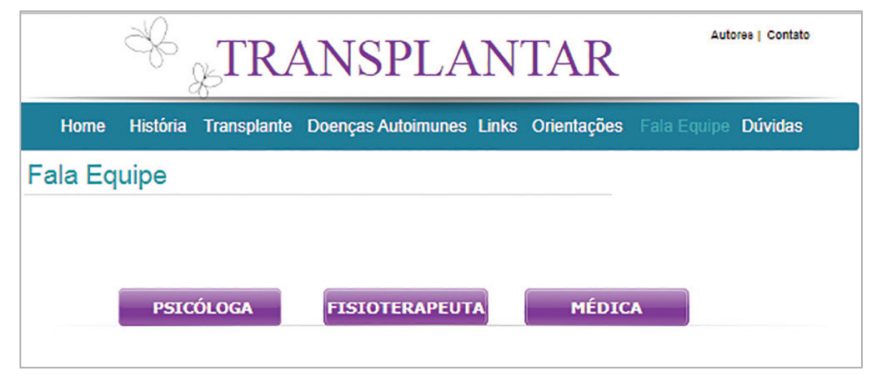

Source: $h$ ttp://www.transplantardai.com.br/

Figure 3 - Screen presentation Speaks Virtual Learning Object Team website Transplantar, Ribeirão Preto, São Paulo, Brazil, 2017

\section{TRANSPLANTAR}

Home Historia Transplante Doenças Autoimunes Links Orientaçōes Fala Equipe Duvidas
Dúvidas Frequentes
É CIRURGIA?
COMO É ESSE CATETER?
CAI MESMO O CABELO?
O QUE POSSO LEVAR AO HOSPITAL?

Source: http://www.transplantardai.com.br/

Figure 4 - Presentation of Frequently Asked Questions about the Virtual Learning Object website Transplantar, Ribeirão Preto, São Paulo, Brazil, 2017

From the initial screen, users can navigate by VLO in the order of the modules or randomly, depending on their preference. The modules were planned independently. In the center of the home page, there is an illustration developed specifically for the VLO, at the request of the main researcher, with the theme butterflies. The image alludes to the unit's logo and associates AHSCT with the butterfly metamorphosis process, since, even in uncertainty, the caterpillar builds its cocoon confident that it will soon turn into a beautiful butterfly. The virtual object will be submitted to an evaluation phase before being used in the education of patients, caregivers and health professionals.

\section{DISCUSSION}

The AHSCT is a recent theme in Brazil, so patients, family members and health professionals still have many doubts, because they have inaccurate information and do not know the procedures and current protocols of treatment. Thus, the purpose of this study was to develop a VLO with information about autoimmune disease transplantation to guide them better. In several contexts, the virtual object has proven to be effective as a communication strategy, expanding the form of relationship and the work and teaching practices ${ }^{(35)}$.

In situations of illness, patients and others involved in this process tend to look for information about their pathologies in the Internet ${ }^{\circ}$. The patient submitted to AHSCT, in particular, lives a long period permeated by many doubts since the period prior to transplantation, and this subject is attractive and very interesting to users ${ }^{(2)}$. Virtual environments and objects, as well as web multiplatforms, are combined in the dissemination of knowledge and advances in the health area. Thus, VLO is a strategy positively evaluated by users and used in nursing for educational purposes, because it offers safe and reliable access to information related to treatment to the patients ${ }^{(36-39)}$.

The elaboration of this VLO was based on the pedagogical framework proposed by Ausubel in 1963, whose principles involve the appreciation of the person's previous knowledge and the recognition of the person as responsible for the search for knowledge. This tool was developed with the purpose of providing information to patients already diagnosed with autoimmune diseases and selected as potential candidates for treatment with AHSCT. Therefore, who have some previous knowledge about the disease, due to the experience with it, and with contact, even if superficial, with the possibility of this treatment announced by the doctor in the most of times.

This first contact with the possibility of AHSCT as a treatment, generally little known, arouses the curiosity of the patient and the desire for more information, making the patient active in his treatment ${ }^{(40)}$. Therefore, this VLO aimed to present the contents in a clear, simple way, with easy navigation, seeking to attract and retain the reader's attention, as well as allow better understanding of the content, expanding their knowledge $\mathrm{e}^{(41)}$.

In this study, we complete the stages of analysis, design, website development and implementation, integrating resources, media and languages, according to the intention and target audience ${ }^{(35)}$. The website was developed to provide a pleasant virtual object, with screen background in clear colors, contents clearly exposed in short and objective texts, in order to facilitate reading. This strategy avoids distractions and ensures better understanding of the content by the learner ${ }^{(36)}$. The contents, resources, icons and menus were created and made available with the care of facilitating and optimizing the search for information and user navigation, as recommended in the literature ${ }^{(42)}$. Thus, the resources were arranged in seven modules on the website, allowing patients and companions to access the information according to their individual needs.

The OVA seeks to work with the multidisciplinary team, because it plays a prominent role in hematopoietic stem cell transplantation units. In addition to the doctor, the team includes nursing professionals, psychologists and physiotherapists, nutritionists, occupational therapists, social workers and dentists ${ }^{(2,9-10)}$. The themes addressed on the website emphasize the impact of transplantation on patients and their families, seeking improvements in quality of life, prevention of functional losses 
in the face of hospitalization and explanation about the care needed to maximize treatment success ${ }^{(9)}$. The multidisciplinary team offers support and safety to patients and their families, by guidance on the various ways of confrontation ${ }^{(2)}$. Therefore, we chose the modules and themes addressed in the OVA based on our clinical practice at the AHSCT unit, especially with regard to the main difficulties faced by patients in relation to the disease and treatment.

In addition, VLO can provide patients with real information about their health situation, correcting paradigms and distorted information. It can also promote reflection about the choice of treatment and contribute to improve the dialogue and answer questions during consultations ${ }^{(43)}$. Finally, because it is a video approach strategy, the literature highlights the VLO as a tool that provides an emotional response of the viewer. The multimedia allows the approach of the patient with the transmitted content, by the expression of emotions in a verbal and non-verbal way ${ }^{(35-36,42,44)}$.

\section{Study limitation}

During the study, we found difficulty in identifying scientific literature about the topics addressed in this work, especially with regard to the role of nursing in AHSCT in autoimmune diseases. In addition, we need to deal with the personal challenge in the field of technology, as it is probably an area not explored before by most of our nurse colleagues. Moreover, as the site has not been tried yet, probably we will find limitations due to difficulty in understanding and/or incomplete guidance.

\section{Contributions to the area of nursing}

We believe that the technology developed is capable of disseminating content and that building attractive and pleasant environments that provide knowledge favors the exercise of nursing in several domains: education, information, care, interaction, among others. We consider that this study will subsidize and contribute to the nursing work in the field of AHSCT in autoimmune diseases, that will be increasingly used as treatment in the national scenario.

\section{CONCLUSION}

The methodology employed allowed the development of the virtual learning object, a tool that can be used to guide and disseminate knowledge about the theme. Thus, patients will have access to quality information and, conversely, the role of nurses will be strengthened in the field of education and health promotion.

In the future, we intend to validate the VLO in terms of appearance and content by consensus of experts in the area of study and information technology and also from the perspective of the user, with a view to improving the media and its operation, reviewing the content according to the needs brought by the target audience. Since knowledge is a dynamic phenomenon that demands continuous updating, we highlight the positive aspect of VLO, as it allows the disclosure of information on the website and, when necessary, the modification of it with agility, in order to provide society with an always updated knowledge.

\section{REFERENCES}

1. Kelsey PJ, Oliveira MC, Badoglio M, Sharrack B, Farge D, Snowden JA. Haematopoietic stem cell transplantation in autoimmune diseases: from basic science to clinical practice. Curr Res TransI Med. 2016;64(2):71-82. doi: 10.1016/j.retram.2016.03.003

2. Santos MA, Marques LAS, Oliveira-Cardoso EA, Mastropietro AP, Teixeira CRS, Zanetti ML. Percepção de pacientes com diabetes mellitus tipo 1 sobre o transplante de células-tronco hematopoéticas. Psicol: Teor e Pesq. 2012;28(4):425-33. doi: 10.1590/\$0102-37722012000400002

3. Snowden JA, Badoglio M, Labopin M, Giebel S, McGrath E, Marjanovic Z, et al. Evolution, trends, outcomes, and economics of hematopoietic stem cell transplantation in severe autoimmune diseases. Blood Adv. 2017;1 (27):2742-55. doi: 10.1182/bloodadvances.2017010041

4. Couri CE, Oliveira MC, Stracieri AB, Moraes DA, Pieroni F, Barros GM, et al. C-peptide levels and insulin independence following autologous nonmyeloablative hematopoietic stem cell transplantation in newly diagnosed type 1 diabetes mellitus. JAMA. 2009;301(15):1573-9. doi: 10.1001/jama.2009.470

5. Sullivan KM, Goldmuntz EA, Keyes-Elstein L, McSweeney PA, Pinckney A, Welch B, et al. Myeloablative autologous stem-cell transplantation for severe scleroderma. N Engl J Med. 2018;378(1):35-47. doi: 10.1056/NEJMoa1703327

6. Saccardi R, Freedman MS, Sormani MP, Atkins H, Farge D, Griffith LM, et al. A prospective, randomized, controlled trial of autologous haematopoietic stem cell transplantation for aggressive multiple sclerosis: a position paper. Mult Scler. 2012;18(6):825-34. doi: $10.1177 / 1352458512438454$

7. Thomson B, Gorospe G, Cooke L, Giesie P, Johnson S. Transitions of care: a hematopoietic stem cell transplantation nursing education project across the trajectory. Clin J Oncol Nurs. 2015;19(4):E74-9. doi: 10.1188/15.CJON.E74-E79.

8. Castro EAB, Andrade AM, Santos KB, Soares TC, Esterci LT. Autocuidado após transplante de medula óssea autólogo no progresso de cuidar pelo enfermeiro. Rev Rene [Internet]. 2012 [cited 2017 Dec 19];13(5):1152-62. Available from: http://www.periodicos.ufc.br/rene/article/ view/4126

9. Silva LMG. Breve reflexão sobre autocuidado no planejamento de alta hospitalar pós-Transplante de medula óssea (TMO): relato de caso. Rev Latino-Am Enfermagem. 2001;9(4):75-82. doi: 10.1590/S0104-11692001000400013

10. Riul S, Aguillar OM. Contribuição à organização de serviços de transplante de medula óssea e a atuação do enfermeiro. Rev Latino-Am Enfermagem. 1997;5(1):49-57. doi: 10.1590/S0104-11691997000100006 
Virtual learning object in hematopoietic stem cell transplantation for autoimmune diseases Zombrilli AF, Leopoldo VC, Oliveira MC, Oliveira MFC, Dolci ME, Braga FTMM, Silveira RCCP.

11. Lima K, Bernardino E. Nursing care in a hematopoietic stem cells transplantation unit. Texto Contexto Enferm. 2014;23(4):845-53. doi: 10.1590/0104-07072014000440013

12. Moreira MA. Aprendizagem significativa: um conceito subjacente In: Moreira MA, Caballero MC, Rodriguez ML, organizadores. Actas del Encuentro Internacional sobre el Aprendizaje Significativo; 1997 Set 15-19; Burgos, Espanha. [Internet]. 1997[cited 2017 Dec 25]. Available from: http://www.if.ufrgs.br/ moreira/apsigsubport.pdf

13. Sousa ATO, Formiga NS, Oliveira SHS, Costa MML, Soares MJGO. A utilização da teoria da aprendizagem significativa no ensino da Enfermagem. Rev Bras Enferm. 2015;68(4):713-22. doi: 10.1590/0034-7167.2015680420i

14. Moreira MA. Aprendizagem significativa, campos conceituais e pedagogia da autonomia: implicações para o ensino. In: Anais online do IX Colóquio Internacional Educação e Contemporaneidade; 2015 Set 17-19; São Cristóvão, SE. [Internet]. 2015[cited 2017 Dec 25]. Available from: http://educonse.com.br/ixcoloquio/Artigo_Aprendizagem.pdf

15. Vasconcelos YL, França SM, Santos FM. Estratégias de ensino aplicáveis na educação à distância. UNOPAR Cient Ciênc Hum Educ [Internet]. 2013 [cited 2017 Dec 19];14(3):183-8. Available from: http://www.pgsskroton.com.br/seer/index.php/ensino/article/view/606/575

16. Salvador PTCO, Bezerril MDS, Mariz CMS, Fernandes MID, Martins JCA, Santos VEP. Virtual learning object and environment: a concept analysis. Rev Bras Enferm. 2017;70(3):572-9. doi: 10.1590/0034-7167-2016-0123

17. Polit DF, Beck CT. Fundamentos pesquisa em enfermagem: avaliação de evidências para a prática da enfermagem. 7a ed. Porto Alegre: Artmed; 2011.

18. Filatro A. Design instrucional contextualizado. Rio de Janeiro: Editora SENAC; 2004.

19. Voltarelli JC. Transplante de células tronco hematopoéticas para doenças auto-imunes no Brasil. Rev Bras Hematol Hemoter. 2002;24(1):913. doi:10.1590/S1516-84842002000100003

20. Burt RK, Cohen BA, Russell E, Spero K, Joshi A, Oyama Y, et al. Hematopoietic stem cell transplantation for progressive multiple sclerosis: failure of a total body irradiation-based conditioning regimen to prevent disease progression in patients with high disability scores. Blood. 2003;102(7):2373-8. doi: 10.1182/blood-2003-03-0877

21. Voltarelli JC, Stracieri ABPL, Oliveira MCB, Godoi DF, Moraes DA, Pieroni F, et al. Transplante de células-tronco hematopoéticas em doenças reumáticas parte 1: experiência internacional. Rev Bras Reumatol. 2005;45(4):229-41. doi:10.1590/S0482-50042005000400007

22. Voltarelli JC, Couri CE, Stracieri AB, Oliveira MC, Moraes DA, Pieroni F, et al. Autologous nonmyeloablative hematopoietic stem cell transplantation in newly diagnosed type 1 diabetes mellitus. JAMA. 2007;297(14):1568-76. doi: 10.1001/jama.297.14.1568

23. Voltarelli JC, Couri CE, Stracieri AB, Oliveira MC, Moraes DA, Pieroni F, et al. Autologous hematopoietic stem cell transplantation for type 1 diabetes. Ann N Y Acad Sci. 2008;1150:220-9. doi: 10.1196/annals.1447.048

24. Couri CE, Voltarelli JC. Potential role of stem cell therapy in type 1 diabetes mellitus. Arq Bras Endocrinol Metabol. 2008;52(2):407-15. doi: $10.1590 /$ S0004-27302008000200029

25. Voltarelli JC, Moraes DA, Ribeiro AAF, Oliveira MC, Rodrigues M, Brum DG, et al . Consenso brasileiro para transplante de célulastronco hematopoéticas para tratamento de doenças autoimunes. Rev Bras Hematol Hemoter. 2010;32(Suppl 1):125-35. doi: 10.1590/ S1516-84842010005000023

26. Burt RK, Shah SJ, Dill K, Grant T, Gheorghiade M, Schroeder J, et al. Autologous non-myeloablative haemopoietic stem-cell transplantation compared with pulse cyclophosphamide once per month for systemic sclerosis (ASSIST): an open-label, randomised phase 2 trial. Lancet. 2011;378(9790):498-506. doi: 10.1016/S0140-6736(11)60982-3

27. Santos MA, Silva AFS, Oliveira-Cardoso EA, Mastropietro AP, Voltarelli JC. Impact of autologous hematopoietic stem cell transplantation on the quality of life of type 1 diabetes mellitus patients. Psicol: Reflex Crít. 2011;24(2):264-271. doi: 10.1590/S0102-79722011000200007

28. van Laar JM, Farge D, Sont JK, Naraghi K, Marjanovic Z, Larghero J, et al. Autologous hematopoietic stem cell transplantation vs intravenous pulse cyclophosphamide in diffuse cutaneous systemic sclerosis: a randomized clinical trial. JAMA. 2014;311(24):2490-8. doi: 10.1001/ jama.2014.6368

29. Malmegrim KC, de Azevedo JT, Arruda LC, Abreu JR, Couri CE, de Oliveira GL, et al. Immunological balance is associated with clinical outcome after autologous hematopoietic stem cell transplantation in type 1 diabetes. Front Immunol. 2017;8:167. doi: 10.3389/ fimmu.2017.00167

30. Atkins HL, Freedman MS. Five Questions Answered: A review of autologous hematopoietic stem cell transplantation for the treatment of multiple sclerosis. Neurotherapeutics. 2017;14(4):888-93. doi: 10.1007/s13311-017-0564-5

31. Guimarães CS, Silveira RCCP, Nilsen L, Rodrigues COM. Transplante autólogo de células tronco hematopoéticas para esclerose sistêmica: ações de enfermagem. Rev Eletr Enf. 2014;16(1):77-83. doi: 10.5216/ree.v16i1.20962

32. Nilsen L, Silveira RCCP. Reações adversas durante condicionamento para transplante autólogo de células tronco hematopoéticas em vigência do uso de globulina antitimocitária [Dissertação]. Ribeirão Preto: Escola de Enfermagem de Ribeirão Preto da Universidade de São Paulo - EERP-USP; 2012.

33. III Reunião de Diretrizes da Sociedade Brasileira de Transplante de Medula Óssea. Diretrizes brasileiras sobre transplante de células tronco hematopoéticas para doenças autoimunes: esclerose sistêmica e esclerose múltipla [Internet]. 2015 [cited 2018 Oct 03]. Available from: http://www.sbtmo.org.br/aula.php?id=22

34. Silva MS. Web design responsivo. São Paulo: Novatec; 2014. 
35. Xelegati R, Évora YDM. Development of a virtual learning environment addressing adverse events in nursing. Rev Latino-Am Enfermagem. 2011;19(5):1181-7. doi: 10.1590/S0104-11692011000500016

36. Rangel EML, Mendes IAC, Cárnio EC, Alves LMM, Crispim JA, Mazzo A, et al. Avaliação, por graduandos de enfermagem, de ambiente virtual de aprendizagem para ensino de fisiologia endócrina. Acta Paul Enferm. 2011;24(3):327-33. doi: 10.1590/S0103-21002011000300004

37. Aguiar RV, Cassiani SHB. Desenvolvimento e avaliação de ambiente virtual de aprendizagem em curso profissionalizante de enfermagem. Rev Latino-Am Enfermagem. 2007;15(6):1086-91. doi: 10.1590/S0104-11692007000600005

38. Silveira RCP, Silva FM. O uso da web e a simulação buscando a excelência no ensino de enfermagem. Rev Enferm UFJF [Internet]. 2016 [cited 2017 Dec 20];2(1):57-62. Available from: https://enfermagem.ufjf.emnuvens.com.br/enfermagem/article/view/72/41

39. Horne B, Newsham A, Velikova G, Liebersbach S, Gilleece M, Wright P. Development and evaluation of a specifically designed website for haematopoietic stem cell transplant patients in Leeds. Eur J Cancer Care (Engl). 2016;25(3):402-18. doi: 10.1111/ecc.12352

40. Garbin HBR, Pereira NAF, Guilam MCR. A internet, o paciente expert e a prática médica: uma análise bibliográfica. Interface. 2008;12(26):57988. doi: 10.1590/S1414-32832008000300010

41. Moran, JM. As mídias na educação. In: Desafios na Comunicação Pessoal. 3a ed. São Paulo: Paulinas; 2007. p. 162-6.

42. Nascimento ACA. Princípios de design na elaboração de material multimídia para à web [Internet]. 2006 [cited 2017 Dec 21]. Available from: http://rived.mec.gov.br/artigos/multimidia.pdf

43. Gabarra LM, Crepaldi MA. A comunicação médico - paciente pediátrico - família na perspectiva da criança. Psicol Argum [Internet]. 2017 [cited 2017 Dec 20];29(65):209-18. Available from: https://periodicos.pucpr.br/index.php/psicologiaargumento/article/view/20335/19607

44. Carvalho M, Oliveira L. As emoções desencadeadas pelas interfaces web: o caso duolingo. Culturas Midiáticas [Internet]. 2013 [cited 2017 Dec 20];(11):1-12. Available from: http://periodicos.ufpb.br/ojs2/index.php/cm/article/view/17545/10130 